\title{
Some geographical aspects of sustainable development with view on Montenegro: a review
}

\author{
Goran Rajovića ${ }^{a}$, Jelisavka Bulatović ${ }^{b}$ \\ Street Vojvode Stepe 252, Belgrade, Serbia \\ Phone: 0038161/19-24-850 \\ Department of Technology and Management, College of Textile Design, \\ Street Starine Novaka 24, Belgrade, Serbia \\ Phone: 003861/3082651, \\ a,bE-mail address: dkgoran.rajovic@gmail.com , jelisavka.bulatovic@gmail.com
}

\begin{abstract}
Sustainable Development refers to the creation and maintenance of social and economic development. In order to achieve this it is necessary to provide interaction between environmental, social and economic components of the system, synchronized in time and space. Each of these interactions has its specific dynamics, requires the involvement of certain resources. Greening the of society expands the array of environmental requirements that are in opposition to traditional economic needs of the accumulation of material wealth and production, which does not take account of the environment. Despite the economic crisis, according to the results of the Euro barometer survey conducted in late March and early April 2014, which included 28,000 respondents from different social and demographic groups, and the 28 members of the European Union, showed that $96 \%$ of people said how they care for the environment, personal matters. To ensure the inclusion of sustainability requirements into development policies and their implementation in practice, Montenegro has prepared and implemented by the National Strategy for Sustainable Development, based on the principles of the Declaration of Rio de Janeiro and Agenda 21, as well as the principles contained in the Declaration and the Johannesburg Plan by implementation.
\end{abstract}

Keywords: Sustainable Development; Environment; European Union; Montenegro

\section{INTRODUCTION}

Sustainable development is now one of the most concepts in science, media and civil society, and yet it is often unknown how sustainability applied in reality. Requirements of sustainable development are imposed as a problem that is increasingly present on the international, national and local level. An increasing number of countries in the world with increasing attention devoted to this issue, a strategic and long-term thinking and improve various aspects of sustainable development in their territory. Implement sustainable development according to the requirements of a very complex undertaking, at any level; is neither simple nor easy. However, the results of sustainable development justify invested a lot of effort into its realization and are visible in the short and long term. In the short term will be noticeable current level of development, and the long-term will create opportunities for 
further improvement and comparison to reference levels within a country as well as internationally [1].

Therefore, ask ourselves whether the there are also social actors who are ready; it is having the ability and determination to make use of any possible model of sustainable development? If so, with whom to political strategies, applicable knowledge and practical skills, achieve sustainable development? We know the most famous definition of sustainable development that emphasizes how we need to meet all their needs without compromising the ability of satisfying the needs of future generations. Given to the growing use of resources, environmental pollution, global climate change, economic and political inequality in the world, the spread of hunger and disease, energy crisis, population growth and other global and local issues, concepts of sustainability are critical to the survival of life as we know it [2].

\section{RESEARCH METHODOLOGY}

The environment is a complex scientific field (complex occurrence) that science can not cover any science alone. Impact of environmental factors when it comes to spatial, regional and urban planning is carried out at is the macro, mezzo and micro levels. For geographical space are evident some differences, so in order to valorize (sometimes) necessary to carry out its division into smaller parts [3]. In parallel with the spatial, ecological concept is of primary importance in geography. That's why it says on the ecological approach in geography [4]. Geography Environment covers many issues of environmental degradation, state of the global environment and living conditions [5]. As a separate field of study in geography is also mentioned geo ecology [6]. Already in mid-twentieth-century notion of geo ecology is accepted by the natural and social sciences and has quickly been recognized as one of the factors of solving environmental problems in total [7]. Objective of this study it was possible to realize the combined use of different research methods. The core of the methodological procedure used in this paper are a method of analysis and synthesis method, whose we are using the data collection work, we managed to derive general conclusions [8-11].

\section{ANALYSIS AND DISCUSSION}

Literature dealing with the definition of the concept of sustainable development is broad and largely inconsistent. The domestic and foreign literature we come across many definitions that are often either too wide or too narrow, that the strategy of sustainable development is seen as part of the social ecology or state policies that this notion gives ideological nature or represent a goal to be sought, but that is economically irrational. Although it has become an indispensable element of government documents and international agreements, the term sustainable development is interpreted in different ways and its strategy of selectively apply from state to state. Many definitions can be found in state documents, sustainable development give a political character which is sustained economic growth aligned with a better use of natural resources, reducing pollution and preserving biodiversity [12].

The most commonly cited definition, which has managed to avoid these pitfalls, it is the definition given in the publication of "Our Common Future", formed as a report of the World Commission on Environment and Development in 1987. By this definition, sustainable development is development that meets the needs of the present without compromising the ability of future generations to meet their own needs [13]. Therefore, it's been more than 
twenty-six years since he began to use the term sustainable development as we know it, but the concept of sustainable development or sustainability was first mentioned in a German forest and is associated with the names of H. C von Carlowitz (1713) and L. Hartiga (1804). He talks about the permanent preservation of forest reserves so that it and the next generation can be used [14].

Following the first conference of the United Nations (UN) on the Protection of the Environment in Stockholm in 1972, where he was involved 113 countries and around 400 different organizations, the idea of sustainable development was first expressed in the document World Conservation Strategy which was brought by three international nongovernmental organizations. This paper focuses primarily ecological sustainability, or the conservation of living resources, and little attention was paid to the broader political, economic and social issues [14]. However, coordinated action by national and international bodies, in 1980, proclaimed the program of action for global sustainability, called the World Conservation Strategy nature, by the International Union for Conservation of Nature, and in 1983 by the United Nations, established by the World Commission on Environment and development. The second United Nations Conference on the Environment held in Nairobi, in 1982, and it warned of uncontrolled industrial development and exploitation of natural resources and the consequences of leaving the environment. World Meteorological Organization, WMO and the UN Environment, UNEP, in 1988 established the Intergovernmental Panel on Climate Change (Intergovernmental Panel on climate change IPCC). During the nineties, significantly expanding is the number of organizations that aim to encourage sustainable development. Among them should be set aside Committee of international development institutions and the environment - CIDI and the Institute for Global Resources - WRI. Many of the existing international institutions, such as the Organization for Economic Co-operation and Development (OECD) and the World Bank (WB) intensively encourage sustainable development, so in 1991 he began to act program Global support environment - GEF, which is reflected in the lending developing countries in addressing environmental problems [15].

Acceptance of the report by the General Assembly of the United Nations gave the "Sustainable Development" a political dimension, followed by the United Nations Conference on Environment and Development, which was held in Rio de Janeiro in Brazil in 1992, set the principles of sustainable development, one of the outcomes of the summit was Agenda 21 - a declaration of intent and commitment to sustainable development in the twenty-first century. From Brundtland reports and "the first Rio de Janeiro," Sustainable development has become generally accepted, and has broad support from international institutions, governments, businesses and the community around the world [16].

This idea of sustainable development is of a general nature and can serve as a guideline in the process of defining national and global politics. However, the Brundtland Commission report at least quadruples the importance of: (1) The concept of sustainable development is seen as meeting present needs without compromising the ability of future generations to meet their needs, according to the first plan development through the concept; that is, sustainable development is a process of change in which the exploitation of resources, investment management, technological development and institutional change must be consistent with the future, not only with current needs, (2) Report Brundtland Commission emphasizes the importance of international cooperation, but also points to the difficulty in achieving such cooperation which can concisely express the attitude:,, Earth is one but the world is not ",(3) Brundtland Commission stressed the need to strengthen national environmental agencies, institutions and organizations, (4) Brundtland Commission proposed the adoption of the UN 
Sustainable Development and maintenance of the International Conference on Environment and Development [17].

The European Union and its Member States are trying a range of activities to promote sustainable development outside the EU, mainly through international bodies such as the example of the World Summit on Sustainable Development held in Johannesburg (Johannesburg) in 2002. It is necessary emphasize that the EU Strategy for Sustainable Development in 2001, based primarily on the economically efficient development, social justice and environmental sustainability, which is given to the external dimension of the establishment of a global partnership for sustainable development (2002). The principle of integration of environmental protection into is the design and implementation of the policy of the European Union confirmed by the Treaty on European Union (1992/1993). Also, meeting in Cardiff in 1998 set the foundation co-ordinate action on the integration of environmental concerns into the plan of the European Union [18].

However, concluding that unsustainable trends outlined in the Strategy from 2001 still exist, and new challenges emerge, a new Sustainable Development Strategy of the European Union in 2006, identifies the following seven key challenges in the European Union: (1) climate change and clean energy, (2) sustainable transport, (3) sustainable consumption and production, (4) the maintenance and management of natural resources, (5) public health, (6) social sustainability, demography and migration (7) global poverty and sustainable development challenges. European Union monitors the implementation of the sustainable development strategy and their analysis published in the biennial report, covering 111 indicators divided into ten chapters. The most important and basic themes of the Strategy and its indicators, the European Union distinguishes the following 10: (1) socio-economic development - the main indicator: Gross domestic product (GDP) per capita, (2) sustainable consumption and production - the main indicator: resource productivity, (3) social inclusion the main indicator: the risk of poverty, (4) demographic changes - the main indicator: the employment rate of older mines (5) Public Health - the main indicator: life expectancy, (6) Climate change and energy - the main indicator: emissions and consumption of renewable energy sources, (7) sustainable transport - the main indicator: energy consumption relative to GDP, (8) water, flora and fauna - the main indicator: an abundance of birds and fish (9) global partnership - the main indicator: by developing (10) good governance - the main indicator is not defined [19].

Sustainable development as a guiding principle of integrating is the operations and the work of many reputable international organizations. Among them is the World Bank, which continually in his work demonstrates commitment to "sustainable globalization", which should contribute to the rapid development in the world while protecting the environment, The International Monetary Fund with the guiding principle of "sustainable economic growth" and the World Trade Organization, which aims to contribute to sustainable development by opening the borders and the removal of barriers to free trade. Sustainable development is the most important part of the Millennium Development Goals of the United Nations established the Millennium Summit in 2000 [20].

According to Gaston et al [21], Martens and Raza [22], Ådnele [23], sustainable development is widely accepted in the private sector, often in the form of CSR (Corporate Social Responsibility). Several voluntary initiatives were established in the last 20 years, including the Global Reporting Initiative, Global Compact), World Business Council on Sustainable Development - WBCSD, Equator Principles and the Extractive Industries Transparency Initiative. Also, have established a number of today is very significant international non such as WWF - World Wide Fund for Nature, Oxfam International and the 
Federation of Friends of the Earth (Friends of the Earth). It is necessary to emphasize the contribution of smaller NGOs to sustainable development throughout the world. By 2009, a total of 106 governments in the world have passed a national strategy for sustainable development.

Although the idea of sustainable development now widely accepted, are still present major problems in the implementation of sustainable development and to evaluate the International Institute for Sustainable Development (IISD), Background Paper prepared for consideration by the High Level Panel on Global Sustainability at its first meeting, 19 September 2010 for the most part so far has been unsuccessful. According to this opinion, the world is not made sufficient progress towards the eradication of poverty, and the integration of the three pillars of sustainable development: economic development, social development and environmental protection remains imperative [24]. So Pokrajac [25] points to the "magic triangle" of sustainable development.

In which economic security includes: (1) increasing the productivity and production of useful goods and services, (2) the reduction of poverty in the world, (3) Ensuring equitable distribution of resources and the constant improvement of equality in all aspects of business, (4) provision of employment, earnings, new investment, trade and distribution of goods, (5) awareness of innovation and entrepreneurship. Social justice refers to: (1) providing and encouraging cultural diversity, (2) maintaining and supporting the institutions of social systems, (3) supporting social justice and gender and racial equality, (4) facilitating participation in decision-making of all segments of society, (5) providing equal educational opportunities for all. Finally ecological balance includes: (1) ensure the maintenance of genetic diversity (2) to support biological production, (3) the development of resistance to the negative impacts on the environment, and to encourage and facilitate recovery in the event of the emergence of negative impacts, (4) ensuring a clean environment and a stable climate, (5) the promotion of eco-efficiency in all parts of society.

Social justice

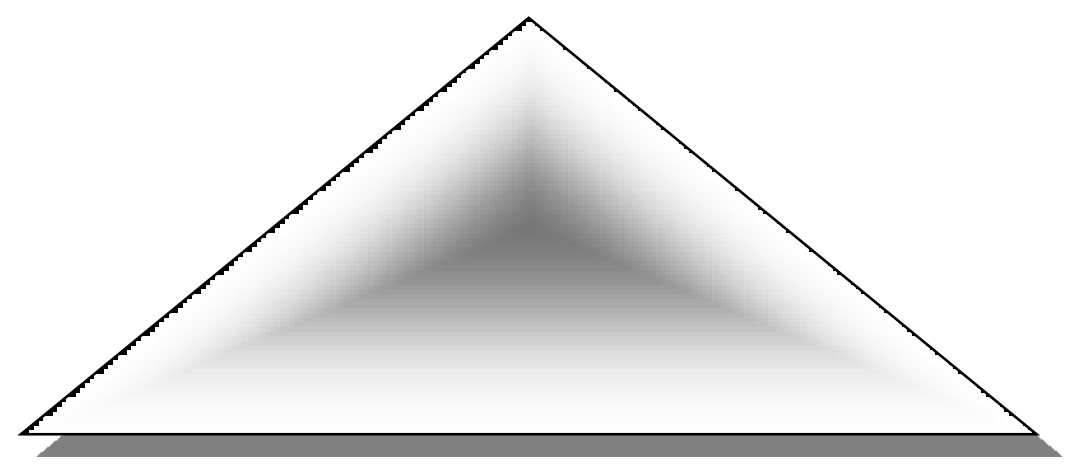

Ecological balance

Economic security

Figure 1. "Magic triangle" of sustainable development [25].

According to Radak et al [26] the basic principles of sustainable development are: the principle of integration, the precautionary principle, the principle of reproducibility and the principle of preventive action. The principle of integration is carried out at three levels: at the 
level of society, the economic level and at the product level. At the level of society, the principle of integration is carried out in the policy, when making decisions with legal restrictions. In doing so, care of the environment includes the public that is the entire population. At the economic level, the principle of integration is the introduction of legal obligations for businesses in order to force them to responsibly manage all types of waste and turned to integrated problem solving. The principle of integration at the product level involves preventive measures to create a legal obligation for manufacturers to pre-define the impact of products on the environment throughout the product lifecycle, from raw materials, production, and finished product to waste. The precautionary principle means that each activity must not rely on the absence of scientific evidence of its impact on the environment. The principle of regeneration involves the preservation of the natural stock of renewable and non-renewable resources - raw materials and energy by increasing the efficiency of the use of these resources, reduces losses, and increase savings and increase recyclability. The principle of prevention is the primary method of integrating the environment into other types of policy and decision-making. This principle is the universal technique for the implementation of sustainable development principles.

According to the Commission on Sustainable Development [27] indicators of sustainable development serve a clear and simple presentation of the collected data on the relationship of society to the social, economic and environmental aspects of sustainable development. In fact, there are a total of 57 indicators of sustainable development according to the United Nations Commission who were divided into 4 groups and grouped into 15 themes and 38 under the theme. The main groups of indicators of sustainable development are: (1) environmental indicators (at example emissions of $\mathrm{CO} 2, \mathrm{SO} 2$ emissions ..., (2) social indicators (for example the impact indicator to the health indicator of the acceptability of consumers from the point of view ..., (3) economic indicators (for example annual energy consumption per capita, the share of energy from renewable sources, generation of hazardous waste ...), (4) institutional indicators (for example number of telephone lines or Internet number of subscribers per 1000 population, expenditure on research and development as a percentage of gross national income ...

When it comes to sustainability Nilsen [28] identifies "weak" and "strong" sustainability. "Weak" Sustainability allows some possibility of substitution of capital, provided that the total amount of capital remains unchanged. A theoretical basis for this view is the most general and accepted definition of sustainable development, which emphasizes the benefits for humanity should not decline over time. With the right Solow [29] points out that economic growth is likely to be sustainable, despite the past spent no reproductive resources, if reduced supplies of resources are compensated by increased quantity and quality of physical capital, and accumulated and intellectual capital. "To be able to maintain a constant consumption in terms of increasing the use of renewable natural resources, the need is unlimited substitution rates of different types of capital"[30]. On the other hand, a "strong" sustainability, argues complementarily of capital, it is the maintenance of individual types of capital at the same time._The concept of "strong" sustainability divided into two directions. The first direction is based on preserving the value of ecological capital, but allows substitution of different values of ecological capital. The second direction is the so-called "very strong sustainability", which is based on the complete preservation of the ecological capital. Application of theoretical principles of strong sustainability in practice means respecting two rules of use of renewable natural resources. First, the utilization rates should be equal to the rate of regeneration (renewal). Second, the loss rate of emissions should be equal to the natural assimilative capacity of the ecosystem [31-32]. 
Despite the economic crisis, according to the results of a special survey of the European Commission's Euro barometer conducted in late March and early April 2014, which included 28,000 respondents from different social and demographic groups, and that the 28 members of the European Union, showed that $96 \%$ of citizens, the how they care for the environment, personal matters. Many respondents also argue that companies, governments, and citizens themselves do more to protect the environment. Environmental activities that citizens of the European Union usually undertaken relates to the separation of waste for recycling and reducing consumption of electricity and water, and are willing to emphasize and allocate more for environmentally friendly products. The Europeans of the environmental issues of most concern pollution, waste and depletion of natural resources and the least noise and spread of invasive species. Most respondents believe that the efficient use of natural resources $(79 \%)$ and protection of the environment (74\%) could stimulate economic growth. And while $80 \%$ of European Union citizens think that the economy is affecting their quality of life, $75 \%$ believe that the state of the environment has the same effect as the economy, while $77 \%$ believe that environmental issues have a direct impact on their daily lives [33]. Respondents are most concerned about pollution: the air (56\%) and water $(50 \%)$, and about the collection of waste and consumption of natural resources. When it comes to consumption and investment by public authorities, $59 \%$ of citizens of the European Union's opinion is that the authorities of their countries should give priority to environmental considerations, no matter the cost. In all states of is the European Union for more than $60 \%$ of respondents wanted to pay more for environmentally friendly products. We note the percentage of respondents plea in Slovakia $76 \%$, Spain $73 \%$, Latvia $78 \%$... The vast majority $(93 \%)$ of the respondents European Union considers that the big polluters should compensate the environmental damage caused and advocate for harsher punishment as the most effective way to cope with environmental problems. At the same time $85 \%$ of respondents believe that they have a role in protecting the environment and most of them are "environmentally friendly behavior". Euro barometer showed that $72 \%$ of respondents European Union separating waste for recycling, $52 \%$ reduction in energy consumption, and 37\% water consumption. Slightly more than a third of respondents (35\%) buy local produce; a straight-third (33\%) reduces waste. While the majority of respondents believe that well informed about environmental issues, $39 \%$ of them pointed out that there is insufficient information about the effects of chemicals in the products that are used daily health. Also, the respondents and their $77 \%$ think it should do more to protect the environment and to large companies and industry are not doing enough in this area, $70 \%$ of respondents expect that national governments do more, and $65 \%$ of the citizens themselves do more. Among the priorities of the respondents stated that in terms of environmental protection it is necessary to sort waste for recycling, which has set aside 54\% of respondents, reducing household energy consumption (39\%) and the use of public transport instead of private cars $(39 \%)$. Almost $80 \%$ of respondents European Union agree that EU legislation is necessary to protect man's environment in their country, and six out of ten of them think about ecology should be decided together, at the European Union. Also, nearly $80 \%$ of respondents believe that the EU should have greater power to check whether the environmentally friendly laws in states applied as expected. At the same time more than $80 \%$ of respondents want to support environmental activities set aside more money in the European Union. In addition, the majority of respondents (56\%) want the European Union do more to protect the environment [33].

One of the countries that aspire to become an integral part of the European Union and Montenegro, which is facing a number of challenges to be overcome, to ensure a rapid and balanced economic development on the one hand, and to improve environmental protection 
on the other. Thus, Montenegro also defined a large number of official documents, which become mandatory for the further its sustainable development. Let's start in 1991 when the National Assembly of the Republic of Montenegro adopted the Declaration on Montenegro as an ecological state in which I defined the strategic commitment to the further development takes place in accordance with the principles and requirements of sustainability. This commitment was confirmed by the Constitution of 1992, in which among other things points out that Montenegro an ecological state is, and where the right to the environment and the duty to preserve and improve, after all, established as a constitutional norm. The need to the need for further work these guidelines led in 2000 to the development of a strategic framework document "Directions of Montenegro as an ecological state"[34].

To ensure the inclusion of sustainability requirements into development policies and their implementation in practice, Montenegro has prepared and implemented a national strategy for sustainable development. As such the strategy: (1) a forward-looking and measures to overcome the identified problems; to the extent possible using existing strategic documents, adding new quality and sustainability perspective, (2) the strategy is realistic in identifying the key issues and is focusing on measures that can be implemented in the short to medium term (bearing in mind the long term goals) (3) The strategy is based on the principle of the division of responsibility between the different actors. It is necessary emphasize that the National Sustainable Development Strategy of Montenegro is based on the principles of the Declaration of Rio de Janeiro and Agenda 21, as well as the principles contained in the Declaration and the Johannesburg Plan by implementation.

Key principles given in these documents, which are the basis for the National Sustainable Development Strategy of Montenegro, are: (1) Integration of environmental concerns into development policies, (2) The internalization of costs related to the environment (i.e. the conversion of external costs of environmental degradation in the internal costs of the polluter / user) through the implementation of the polluter / user pays, (3) The participation of all social actors / stakeholders in decision-making, consultation, dialogue and partnership, (4) Access to information and justice, (5) Equity between generations and equity within the same generation (including gender equality), (6) The precautionary principle, it is a requirement to preserve the natural equilibrium in the absence of reliable information about a specific problem, (7) The principle of hierarchy and interdependence between the local and global levels and (8) Access to services and financial resources necessary to meet basic needs. These principles are the prism through which the existing problems and challenges for sustainable development in Montenegro, it is a framework which defines the objectives, tasks and measures for the implementation of sustainable development policies [35].

National Strategy for Sustainable Development defines the concept of sustainable development of Montenegro through the eight principles, as follows: (1) Balanced and equitable economic growth that can be sustained over a longer period of time, (2) poverty reduction, (3) Participation of all stakeholders in the decision-making process: dialogue, trust and social capital, (4) Careful management and conservation of non-renewable resources, (5) The rational / sustainable use of energy and natural resources, (6) Waste minimization, effective prevention and control of pollution, minimizing environmental risks, (7) Improving the education and health systems and improvements in gender equality and (8) Protection of cultural identity [36].

As part of the sustainable development of Montenegro in Podgorica, it is officially 2014, started working the Center for Sustainable Development of Montenegro. It was created as a joint project of the Ministry of Sustainable Development and Tourism of the Government of Montenegro and the United Nations Development Programmed (UNDP). The work of the 
Center will focus on sustainable development, renewable energy, energy efficiency, resource management and eco-systems, adaptation to the effects of climate change and security in the environment. The budget of the Centre for Sustainable Development projects aimed at 3.1 million dollars, and will primarily be focused on Montenegro, and then the states in the region, as well as partners and service users. In addition to sustainable development projects, the Centre for Sustainable Development will participate in agreements in the field of environmental research and policy analysis, as well as the development of a prototype of the latest scientific, research and technological approaches to further the objectives of sustainable development [37].

According to Fabris [38] suggest that the concept of sustainable development more widely used in the program documents and strategies, but in the practical conduct of economic policy. Although in recent years, with notable progress in protecting the environment, which is primarily manifested in the adoption of new legislation, the ratification of international conventions, establishing the Agency for Environmental Protection and the increase in the number of protected species, it is still much to be done in order to achieve environmental sustainability. The priority tasks Fabris [38] highlights: emergency rehabilitation of endangered sites, punishing all those who violate the legislation in the field of ecology, additional taxing the biggest polluters, raising public awareness and involvement of the private sector on the principle of public-private partnerships to expand the network of protected areas and determine their controls, increase the network of landfills, recycling rate and waste form landfill for hazardous materials, to stop excessive urbanization narrow belt around the seashore, for all large infrastructure projects before the start of their implementation to conduct an analysis of their environmental impact, strengthen the human resource capacity of the Agency for Environmental Protection ...

Our research evidence based on similar studies Ćuk [39] states battalions problems on the road to establishing a sustainable development in Montenegro, including the indispensable material component, as well as intellectual. Montenegro missing money, but also experts who will work on projects that are placed before it on is the road to sustainable development as a component of environmental protection. Problems that arise in Montenegro can be classified in the following way: (1) Budgetary constraints, reinforced by the economic crisis, high domestic deficits, high unemployment, (2) The slow pace of reform slowed the fight against organized crime and corruption, (3) unfavorable demographic structure, and poor demographic trends, (4) Poor infrastructure in the field of the environment, (5) unfavorable parameters of air quality and drinking water...

Practice in terms of (not) to harmonize the goals of sustainable development in Serbia and Montenegro to Lješević [40] it is necessary to divide into two groups, depending on the profession who participate in making plans and programs, including: sector approach that dominates urbanisms and planners, where all aspects of care expressed by segments of appropriate titles and the approach practiced by economists and people engaged in social development in which environmental development component generally treated as a function of socio - economic development. The above practice (both approaches) is inconsistent with modern conceptions of development, which means the integrity of the approach. Recognizing the integral approach to the problem of regulating the protection of the environment should be so "all aspects, principles and criteria of protection included in individual development documents or comprehensive, in documents of sustainable development" [41]. 


\section{CONCLUSIONS}

Protecting the environment is a global problem and therefore requires global solutions. It is not possible to protect the environment in a manner preventing economic development, but it should focus on how to achieve sustainable development. The term sustainable development entered the general vocabulary of the eighties of the twentieth century and shows link between development and environmental protection, and it is definitely accepted at the conference in Rio de Janeiro in 1992. The success of the concept of sustainable development at the global level is possible the realization of the main political objectives and the implementation of social change. Sustainable development can be defined as the ratio between the dynamic economic system that develops human and larger dynamic ecological systems that are slow to change and must be in ecological balance [42].

Sustainable development refers to the creation and maintenance of social and economic development. In order to achieve this it is necessary to provide interaction between environmental, social and economic components of the system, synchronized in time and space. Each of these interactions has its specific dynamics, requires the involvement of certain resources. If we observe the dynamics, it arises from changes in the environment and changes in policy and strategy development and in particular the limitations in resources [43].

Environmental crisis as a fundamental feature of modern civilization, leads to the fulfillment of numerous human needs further development and even survival. The first and second industrial revolutions were not sympathetic to the environment, and in the second half of the twentieth century indicate disruption of the ecological balance as a result of the mismatch between the techno sphere, social sphere and the sphere and are looking for possible ways to overcome the problems and resolve "conflict" between natures - society. Greening the of society expands the array of environmental requirements that are in opposition to traditional economic needs of the accumulation of material wealth and production, which does not take account of the environment [44].

In conclusion, according to Rogošić-Pavić [45] it is impossible to have a healthy society and economy quality in a world where there is so much poverty and environmental degradation. Economic development cannot be stopped, but it should change direction to become less damaging to the environment and social development. Convert those insights into action and move toward sustainable forms of development and ways of life is a challenge in today's world. With such a set objective, the environment becomes much broader than the traditional view, according to which the predominantly engaged in the protection of human health and the preservation of the integrity of ecological systems.

\section{References}

[1] Sustainable Development Indicators for Sustainable Development, Available from: http://www.agroekonomija.wordpress.com (08. 10 2014).

[2] Obstacles and Opportunities for Sustainable Development, Available from: http://www.bib.irb.hr (09.10 2014).

[3] M. Spahić, Osnovi geoekologije, Harfo-graf, Tuzla, 1999.

[4] W. Marsh, J. Grossa, Environmental Geography Science, Land Useand Earth System, John Wiley \& Sons, New York, 2003.

[5] M. Matas, Geografski pristup okolišu, Visoka učiteljska škola, Petrinja, 2001. 
[6] Н. Ясаманов, Основи геоекологии, Академия, Moskow, 2003.

[7] G.Rajović, Istraživanje i razvoj 13 ( 1-2) (2007) 61-66.

[8] G. Rajović, Istraživanje i razvoj 14 ( 28-29)(2008) 193-196.

[9] G. Rajović, J. Bulatović, Ecologica 15 (51)(2008) 45-52.

[10] J. Novak-Marcincin, D. Gîfu, A. Nicolescu, International Letters of Social and Humanistic Sciences 30 (2014) 176-183.

[11] A. Borowski, International Letters of Social and Humanistic Sciences 11 (2014) 1-168.

[12] D. Nadić, Godišnjak Fakulteta Političkih nauke 5(6) (2011) 213-224.

[13] United nations, Report of the World Commission on Environment and Development, General Assembly Resolution 42/187 (1987), New York, Available from: http://www.daccess-dds-ny.un.org (05.10 2014).

[14] F. Jambrović, Zbornik radova Međimurskog veleučilišta u Čakovcu 2(1) (2011) 14-27.

[15] M. Unković, N. Kordić, 10 International scientific meeting Singerija, 2011, University Singerija, p. 11-21.

[16] R. Morgan, Transforming Law and Institution, Indigenous Peoples, the United Nations and Human Rights, Burlington, VT Ashgate, 2011.

[17] S.B. Milenović, Ekološka ekonomija - teorija i praksa, Univerzitet u Nišu, Fakultet zaštite na radu, 2000.

[18] S. Baker, Politics of Sustainable Development, Routledge, 2012.

[19] S. Rapaić, Medjunarodni problemi 64(3) (2012) 339-358.

[20] T. Pogge, Journal of Human Development 5(3) (2004) 377-397.

[21] N. Gaston, M.A. Khalid, Globalization and Economic Integration: Winners and Losers in the Asia-Pacific, Edward Elgar Publishing, 2010.

[22] P. Martens, M. Raza, Sustainability 2(1) (2010) 280-293.

[23] A.A. Adenle, Journal of Genetic Engineering and Biotechnology 9(2) (2011) 83-95.

[24] O. Das, Environmental protection, security and armed conflict: a sustainable development perspective, Cheltenham, UK ; Northampton, MA : Edward Elgar Pub, 2013.

[25] S. Pokrajac S., Škola biznisa 2009 21-30.

[26] B. Radak,K. Subotić,P. Popović, 32 National Conference on Quality "Quality Festival" 19-21 m a j 2005., Kragujevac, p. 47-50.

[27] Commission on Sustainable Development (2014), Work Programmed on Indicators of Sustainable Development, E/CN.17/2001/4/Add.1.

[28] R.H. Nilsen, Ecological Economics 69 (2010) 495-501.

[29] R. Solow, Scandinavian Journal of Economics 88 (1986) 141-149.

[30] U.R. Ayres, C.J. Van Den Bergh, M.J. Gowdy, Viewpoint: weak versus strong sustainability (No. 98-103/3), Tinbergen Institute Discussion Paper, 1998. 
[31] W. Hediger, International Journal of Social Economics 26(7/8/9) (1999) 1120-1144.

[32] W. Hediger, Ecological economics 32(3)(2000) 481-492.

[33] EurActiv Srbija, Europeans are willing to pay more for environmentally friendly products (European Commission Euro barometer survey (2014), Available from: http://www.euractiv.rs (11.10 2014).

[34] FORS Montenegro - Foundation for the Development of Northern Montenegro, Vision of sustainable development in Montenegro (2014), Available from:

http://www.forsmontenegro.org (06.10 2014).

[35] D. Nadić, Teme 36 (2) (2012) 501-523.

[36] Ministry of Economy of the Government of Montenegro, Sustainable Development Strategy, Available from: http://www.oie-res.me (06.10 2014).

[37] Center for Sustainable Development of Montenegro, Presentation, Available from: http://www.me.undp.org (07.10 2014).

[38] N. Fabris, Teme 37(3) (2013) 1303-1319.

[39] T. Ćuk, Issues of sustainable development in Serbia (2011), Available from: http://www.cqm.rs (10.10 2014).

[40] M. Lješević, Zbornik sa naučno stručnog skupa „,Planska i normativna zaštita prostora $i$ životne sredine”, Asocijacija prostornih planera Srbije, p. 299-310.

[41] M. Vujošević, B. Božović, Zbornik sa naučno-stručnog skupa „Planska i normativna zaštita prostora i životne sredine”, Asocijacija prostornih planera Srbije, Belgrade, p. 289-298.

[42] M. Drljača, International Conference Quality Week, Quality and Excellence 1(1-2) (2012) 20-26.

[43] S. Arsovski, R. Milićević, A. Arsić-Kokić, 37 National Conference on Quality, 5 national conference on quality of life, 19-21 maj, 2010, Kragujevac, p. 1-7.

[44] V. Miltojević, Teme 30(3) (2006) 427-440.

[45] L. Rogošić-Pavić, Održivi razvoj, Odraz, 2010. 